\title{
Adapting to Pacific Island mangrove responses to sea level rise and climate change
}

\section{Eric L. Gilman ${ }^{1,15, *}$, Joanna Ellison ${ }^{1}$, Vainuupo Jungblut ${ }^{2}$, Hanneke Van Lavieren ${ }^{3}$, Lisette Wilson ${ }^{4}$, Francis Areki ${ }^{5}$, Genevieve Brighouse ${ }^{6}$, John Bungitak ${ }^{7}$, Eunice Dus ${ }^{8}$, Marion Henry ${ }^{9}$, Mandes Kilman ${ }^{10}$, Elizabeth Matthews ${ }^{11}$, Ierupaala Sauni Jr. ${ }^{6}$, Nenenteiti Teariki-Ruatu ${ }^{12}$, Sione Tukia ${ }^{13}$, Kathy Yuknavage ${ }^{14}$}

${ }^{1}$ University of Tasmania, School of Geography and Environmental Studies, Locked Bag 1-376 Launceston, Tasmania 7250, Australia

${ }^{2}$ Secretariat of the Pacific Regional Environment Programme, PO Box 240, Apia, Samoa

${ }^{3}$ United Nations Environment Programme, Regional Seas Programme, PO Box 30552 Room T-232, Nairobi, Kenya ${ }^{4}$ WWF-South Pacific, PO Box 8280, Boroko, NCD, Papua New Guinea

${ }^{5}$ WWF-Fiji, 4 Ma'afu Street, Private Mail Bag, Suva, Fiji

${ }^{6}$ Coastal Management Program, Utulei Executive Office Building, Pago Pago, American Samoa 96799, USA

${ }^{7}$ Environmental Protection Authority, PO Box 1322, Majuro, MH 96960, Republic of the Marshall Islands

${ }^{8}$ Wildlife Conservation Society, PO Box 277, Goroka, Eastern Highlands Province, Papua New Guinea

${ }^{9}$ Department of Economic Affairs, PO Box PS12, Palikir, Pohnpei, FM 96941, Federated States of Micronesia

${ }^{10}$ Primary Resources Consulting Company, PO Box 1691, Port Vila, Vanuatu

${ }^{11}$ Palau Conservation Society, Box 1811, Koror, PW 96940, Palau

${ }^{12}$ Ministry of Environment, Land, and Agricultural Development, PO Box 234, Bikenibeu, Tarawa, Kiribati

${ }^{13}$ Department of Environment, PO Box 917, Nuku'alofa, Tonga

${ }^{14}$ Commonwealth of the Northern Mariana Islands Coastal Resources Management Office, Box 10007, Saipan MP 96950, USA

${ }^{15}$ Present address: 2718 Napuaa Place, Honolulu, Hawaii 96822, USA

\begin{abstract}
Stresses associated with effects of climate change, including rise in relative mean sea level, present one set of threats to mangroves. Coastal development and ecosystems in the Pacific Islands region are particularly vulnerable to climate change effects. We investigated the capacity of Pacific Island countries and territories to assess mangrove vulnerability to the effects of climate change, and their capacity to adapt to mangrove responses to these forces. Technical and institutional capacity-building priorities include: (1) strengthening management frameworks to conduct site-specific assessment of mangrove vulnerability and incorporate resulting information into land-use plans to prepare for any landward mangrove migration and offsetting anticipated losses; (2) reducing and eliminating stresses on and rehabilitating mangroves, in part, to increase mangrove resilience to climate change effects; and (3) augmenting abilities to establish mangrove baselines, and monitor gradual changes using standardized techniques through a regional network to distinguish local and climate change effects on mangroves. Other priorities are to: (4) assess how mangrove margins have changed over recent decades; (5) determine projections of trends in mean relative sea level and trends in the frequency and elevation of extreme high water events; $(6)$ measure trends in changes in elevations of mangrove surfaces; and (7) incorporate this information into land-use planning processes. Also in (8) some locations require spatial imagery showing topography and locations of mangroves and coastal development. Land-use planners can use information from assessments predicting shoreline responses to projected sea level rise and other climate change effects to reduce risks to coastal development, human safety, and coastal ecosystems. This advanced planning enables coastal managers to minimize social disruption and cost, minimize losses of valued coastal ecosystems, and maximize available options.
\end{abstract}

KEY WORDS: Mangrove $\cdot$ Sea level rise $\cdot$ Climate change $\cdot$ Land-use planning $\cdot$ Pacific Islands

\section{INTRODUCTION}

Accurate predictions of changes to coastal ecosystem area and health, including in response to climate change effects such as projected relative sea level rise, enables advanced planning appropriate for specific sections of coastline to minimize and offset anticipated losses, and reduce threats to coastal development and 
human safety (Titus 1991, Mullane \& Suzuki 1997, Ellison 2004, Gilman et al. in press). Relative sea level rise is a major factor contributing to recent losses and projected future reductions in the area of valued coastal habitats, including mangroves and other tidal wetlands, with concomitant increased threat to human safety and shoreline development from coastal hazards (Gilman et al. in press). Global sea level rise is one of the more certain outcomes of global warming; 10 to $20 \mathrm{~cm}$ occurred during the last century, and several climate models project an accelerated rate of sea level rise over coming decades (Church et al. 2001, 2004a, Holgate \& Woodworth 2004).

Over the past few decades, the 10 countries and territories with native mangroves in the Pacific Islands region experienced an average rise in relative sea level of $2 \mathrm{~mm} \mathrm{yr}^{-1}$. Based on general estimates of mangrove sedimentation rates (Ellison \& Stoddart 1991), and the possibility that subsurface sediment subsidence from organic matter decomposition, sediment compaction, and fluctuations in sediment water storage and water table levels may result in substantially higher rates of sea level rise relative to the mangrove surface (Krauss et al. 2003), island mangroves could experience serious problems due to rising sea level, and low island mangroves may already be under stress. Gilman et al. (in press) determine that American Samoa could experience a $50 \%$ loss in mangrove area by the year 2100 . A $12 \%$ reduction is possible in the Pacific Islands region due to mangrove responses to relative sea level rise when employing the Intergovernmental Panel on Climate Change's upper projection for global sea level rise through the year 2100 .

Shoreline development and coastal ecosystems are particularly vulnerable to small increases in sea level and other climate change effects in the Pacific Islands region. Many of the low islands do not exceed $4 \mathrm{~m}$ above current mean sea level, and even on high islands, most development is located on narrow coastal plains. Small island states have limited capacity to adapt to relative sea level rise, including accommodating landward migration of mangroves and other coastal ecosystems. This is a result of their small land mass, high population densities and population growth rates, limited funds, poorly developed infrastructure, and susceptibility to damage from natural disasters (Nurse et al. 2001). It may not be physically or economically feasible for many small island state communities to retreat from a landward-migrating mangrove and other coastal habitats, or to establish zoning setbacks from coastal habitats for new development.

Pacific Island governments have recognized the value of mangroves and the need to augment conservation efforts (e.g. South Pacific Regional Environment Programme 1999a). The Pacific Islands contain roughly
$3 \%$ of the world's mangrove area, a small area in global terms, but each island group has a unique mangrove community structure (Ellison 2000) and mangroves provide site-specific functions and values (e.g. Lewis 1992, Gilman 1998). Reduced mangrove area and health will increase the threat to human safety and shoreline development from coastal hazards such as erosion, flooding, and storm waves and surges. Mangrove loss will also reduce coastal water quality and biodiversity, eliminate fish and crustacean nursery habitat, adversely affect adjacent coastal habitats, and eliminate a major resource for human communities that traditionally rely on mangroves for numerous products and services (Ramsar Secretariat 2001). Mangrove destruction can also release large quantities of stored carbon and exacerbate global warming trends (Ramsar Secretariat 2001).

Land-use planners can obtain information from assessments predicting shoreline responses to projected relative sea level rise and other climate change effects over coming decades to mitigate anticipated losses of coastal habitats and avoid and minimize damage to coastal development. In this study, we assess the capacity of Pacific Island countries and territories to determine vulnerability and adapt to mangrove responses to climate change effects. Results highlight priority technical and institutional capacity-building needs nationally and regionally.

\subsection{Mangrove responses to relative sea level rise and other climate change effects}

When relative sea level rise is the predominant force shaping mangrove position, the landscape-level responses of mangroves over decadal and longer periods can be predicted based on reconstruction of the paleoenvironmental response of mangroves to past sea level fluctuations (Ellison \& Stoddart 1991, Woodroffe 1995, Ellison 1993, 2000, Gilman 2004, Gilman et al. in press). Such predictions can be based on (1) the mean sea level change rate relative to the mangrove surface, (2) the mangrove's physiographic setting (slope of the land adjacent to the mangrove, slope of the mangrove, and presence of obstacles to landward migration), and (3) erosion or progradation rate of the mangrove seaward margin (Ellison \& Stoddart 1991, Ellison 1993, 2000, 2001, Woodroffe 1995, Alleng 1998, Gilman 2004, Gilman et al. in press). There are 3 general scenarios for mangrove response to relative sea level rise, given a landscapelevel scale and time period of decades or longer (Fig. 1):

(A) No change in relative sea level: When sea level is not changing relative to the mangrove surface, the mangrove margins will remain in the same location (Fig. 1A). 
(B) Relative sea level drop: When sea level is dropping relative to the mangrove surface, this forces the mangrove seaward and landward boundaries to migrate seaward (Fig. 1B). The mangrove may also expand laterally if areas adjacent to the mangrove, which are currently at a lower elevation than the mangrove surface, develop hydrologic conditions (period, depth and frequency of inundation) suitable for mangrove establishment.

(C) Relative sea level rise: If sea level is rising relative to the mangrove surface, the mangrove's seaward and landward margins retreat landward where unobstructed, as mangrove species zones migrate inland in concert with migrating environmental conditions, such as period, frequency and depth of inundation and salinity (Fig. 1C). The mangrove may also expand laterally if areas adjacent to the mangrove, which are

\section{A. No change in sea level relative to mangrove surface.}

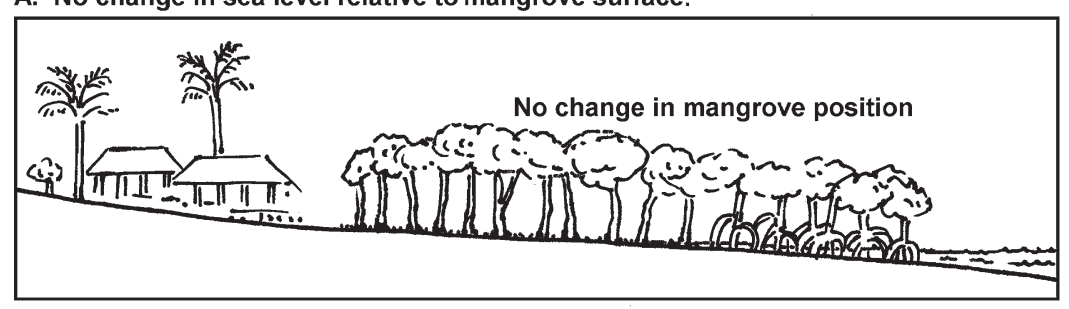

B. Sea level drops relative to the mangrove surface.

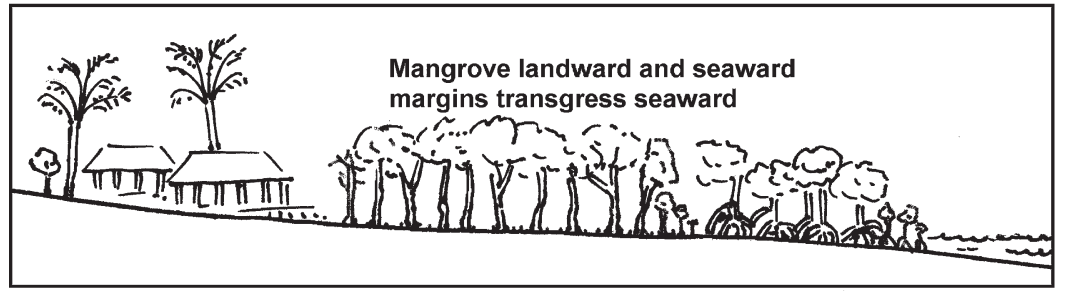

C. Sea level rises relative to the mangrove surface, and there are no obstacles to the mangrove's landward transgression.

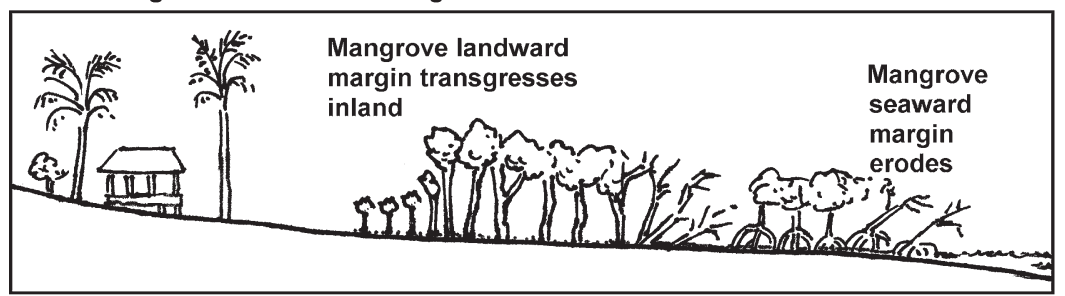

D. Sea level rises relative to the mangrove surface and landward transgression is obstructed.

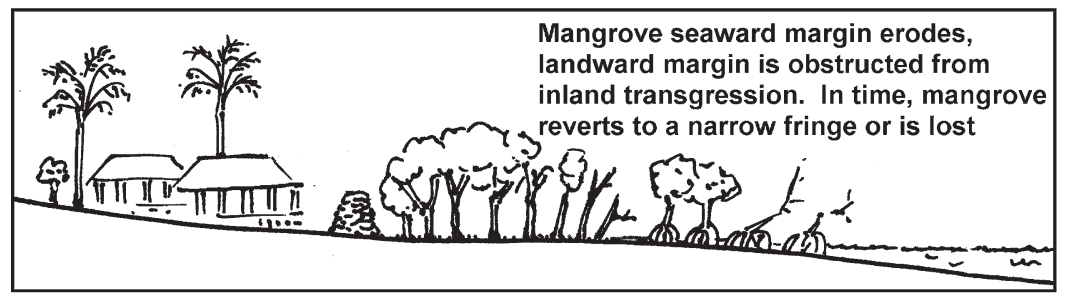

Fig. 1. Scenarios for generalized mangrove responses to relative sea level rise currently at a higher elevation than the mangrove surface, develop a suitable hydrologic regime. Depending on the ability of individual true mangrove species to colonize newly available habitat at a rate that keeps pace with the rate of relative sea level rise, the slope of adjacent land and the presence of any obstacles to landward migration of the landward boundary of the mangrove, such as seawalls and other shoreline protection structures, some sites will revert to a narrow mangrove fringe or experience extirpation of the mangrove community (Fig. 1D).

However, over small temporal and spatial scales, and re natural and anthropogenic forces other than ing relative sea level exert a larger influence on will be variable (SCOR Working Group 1991, Woodroffe 1995, Gilman et al. in press). For example, forces affecting sediment-budget balances, including changes in sediment budgets from rivers, variations in coastal currents, wind directions and strength, and construction of seawalls and other shoreline erosion control structures, can produce erosion or accretion of the mangrove seaward margin irrespective of any change in sea level.

In addition to altered sediment inputs, several other forces can affect mangrove margin position, as well as their structure and health. Outcomes of global climate change besides global sea level rise, such as changes in precipitation and resulting alterations to the mangrove salinity gradient, increases in air and sea surface temperatures, changes in frequency and intensity of storms, changes in prevailing ocean wave heights and direction, and changes in tidal regimes may affect coastal systems, including mangroves. For instance, Snedaker (1993) hypothesizes that the mangrove species Rhizophora mangle will increase peat production with increased freshwater inputs (for instance, if precipitation increases or relative sea level is dropping), but will experience a net loss of peat if salinity increases (for instance, if relative sea level is rising or precipitation is decreasing), as the increased availability of sulfate in seawater would increase anaerobic decomposition of peat, increasing the mangrove's vulnerability to any rise in relative sea level. Areas with decreased precipita- 
tion will have a smaller water input to groundwater and less freshwater surface water input to mangroves, increasing salinity. Increased salinity decreases mangrove net primary productivity, growth, and seedling survival, and may possibly change competition between mangrove species (Ellison 2000, 2004). Decreased rainfall and increased evaporation will reduce the extent of mangrove areas, with a conversion of landward zones to hypersaline flats, and there will be a decrease in diversity of mangrove zones and growth (Ellison 2000). Mangrove areas experiencing increased rainfall will experience an increase in area, with mangrove colonization of previously unvegetated areas of the landward fringe, and there will be an increase in diversity of mangrove zones and growth rates (Ellison 2000). Areas with higher rainfall have higher mangrove diversity and productivity due to higher supply of fluvial sediment and nutrients, as well as reduced exposure to sulfate and reduced salinity (McKee 1993, Snedaker 1993, Ellison 2000, 2004). However, projected changes to these other global climate parameters, including Pacific precipitation patterns, are less certain than global change in sea level, and the response of mangroves and other coastal systems to these changes are not well understood (Ellison 2000, Houghton et al. 2001, McLean et al. 2001).

Other forces that can affect mangroves include changing nutrient, freshwater, and pollutant inputs, clearing of mangrove vegetation, filling, displacing native species with alien invasive species, and vegetation loss from insect infestations, fungal flora pathogens, and other diseases (Ellison 1993, 1999, Gilman 1999, Saintilan \& Wilton 2001). These pressures can also reduce mangrove resilience to the additional stress of relative sea level rise and other climate change effects. The projected increase in the frequency and elevations of extreme high water events in response to climate change (Church et al. 2001, 2004b, Woodworth \& Blackman 2002, 2004, Gilman et al. 2005) could also affect the position and health of mangroves by altering salinity, recruitment, and inundation, in addition to changing the wetland sediment budget.

Also, degradation of adjacent coastal ecosystems from relative sea level rise and climate change may reduce mangrove health. Mangroves are functionally linked to neighboring coastal ecosystems, including seagrass beds, coral reefs, and upland habitat, although the functional links are not fully understood. For instance, mangroves of low islands and atolls, which receive a proportion of sediment supply from coral reefs, may experience lower sedimentation rates and increased susceptibility to relative sea level rise if coral reefs become less productive due to climate change effects.

\subsection{National, regional and international initiatives}

Due to anticipated effects of climate change in the Pacific Islands region (Fig. 2), several international and regional initiatives discuss the severity of this threat and provide general guidelines for planning. However, there have been few site-based vulnerability assessments and few planning initiatives to manage mangroves responses to sea level rise and other climate change effects.

There have been several national or island-scale vulnerability assessments in Pacific Island countries and territories that provide qualitative assessments to describe the anticipated responses of coastal systems to projected sea level and other climate change effects and concomitant threats to developed portions of the coastal zone. For example, Phillips (2000) describes the vulnerability of Vanuatu's coastal villages to sea level rise, referencing global sea level rise models produced by the Intergovernmental Panel on Climate Change and other projected global climate change parameters (temperature and precipitation), as a basis for hypothesizing possible environmental, social, and economic effects. Other vulnerability assessments have established the locations and elevations of coastal habitats and development, and use global or relative sea level change projections to make rough predictions of the sections of coastline that will be affected. For example, Solomon et al. (1997) create a geographic information system (GIS) of a developed stretch of the coastline of Viti Levu, Fiji using topographic maps to identify the locations and elevations of coastal development, including sea walls, revetments, and other shoreline protective structures. They then use this GIS to assess the vulnerability of the coastline to inundation from 4 sea level rise scenarios (a rise of $0,0.25,0.5$ and $1 \mathrm{~m}$ ) and storm surges. This approach to conducting a vulnerability assessment does not incorporate natural coastal ecosystem response to changes in relative sea level and other climate change effects.

All 12 Pacific Island countries with indigenous mangroves are Parties to United Nations Framework Convention on Climate Change (UNFCCC). Of these, 11 countries (Kiribati, Marshall Islands, Federated States of Micronesia, Nauru, Palau, Papua New Guinea, Samoa, Solomon Islands, Tonga, Tuvalu, and Vanuatu) have submitted an initial National Communication to the UNFCCC. Fiji has not yet submitted a National Communication. The 11 initial National Communications discuss general considerations and guidelines related to coastal ecosystem vulnerability and adaptation to future sea level and climate change (Federated States of Micronesia 1997, Government of Samoa 1999, Government of Tuvalu 1999, Kiribati Government 1999, Republic of Nauru 1999, Republic of Vanuatu 1999, 


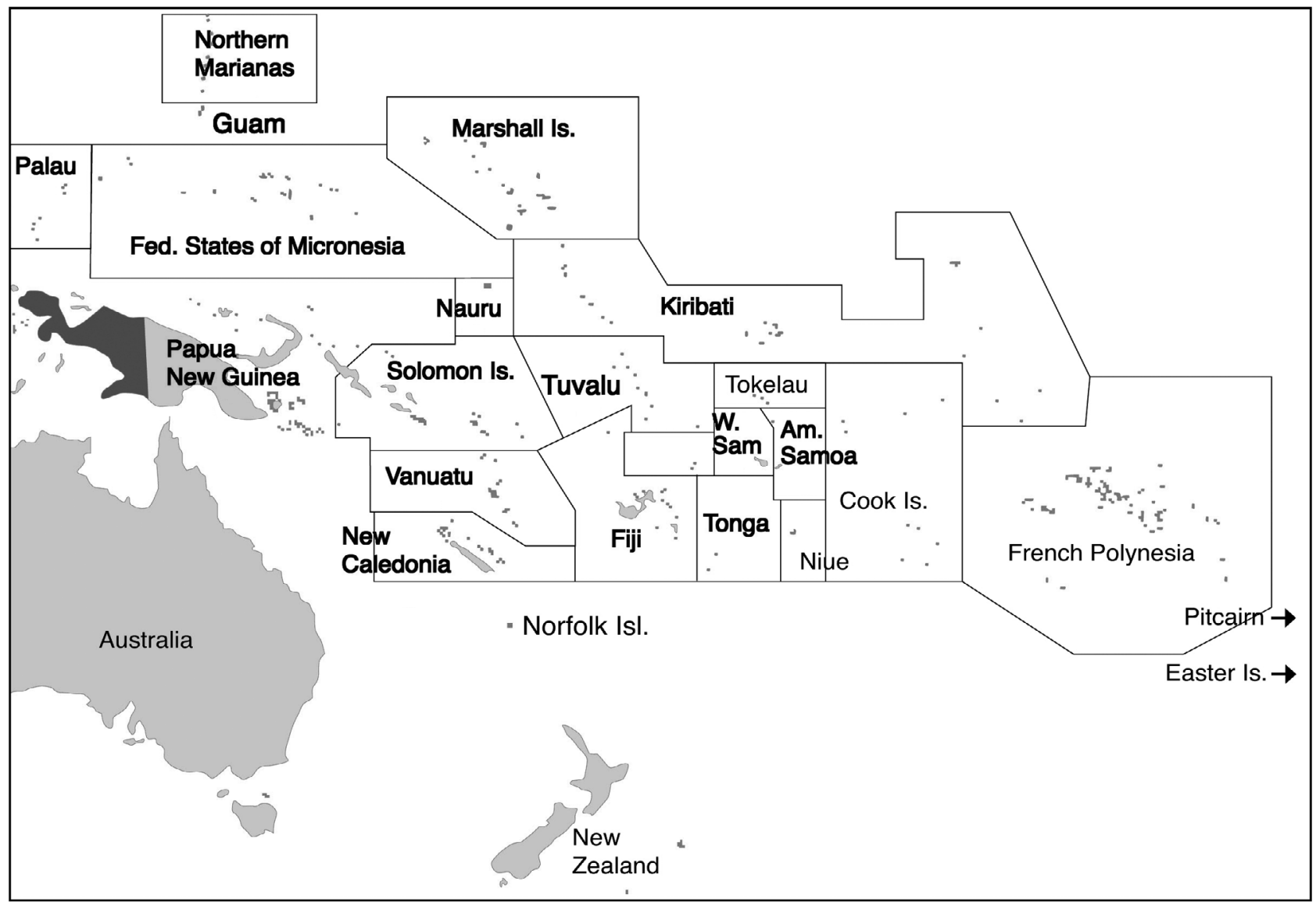

Fig. 2. Pacific Islands region and location of the 12 Pacific Island countries and 4 territories with indigenous mangroves (bold)

Papua New Guinea Government 2000, Republic of the Marshall Islands Environmental Protection Authority 2000, Republic of Palau Office of Environmental Response and Coordination 2002, Solomon Islands Government 2004, Kingdom of Tonga 2005). A review of these reports highlights that there is a gap in information on anticipated site-specific responses of mangroves and other coastal ecosystems to climate change effects and site-specific strategies for adaptation. Examples of some of the general adaptation strategies to manage mangrove and other coastal ecosystem responses to climate change effects identified in several of these national communication reports include: - Establishing zoning rules for setbacks of new development from mangroves

- Retreating to higher ground or off-island for appropriate sections of coastline as a last resort

- Identifying sections of coastal areas vulnerable to flooding and inundation to guide future development

- Fortifying relevant sections of developed coastline

These examples are representative of the level of specificity in the National Communication reports to assess the vulnerability of and adapt to coastal ecosys- tem response to sea level and other climate change effects.

The South Pacific Sea Level and Climate Monitoring Project was initiated in 1991 to establish stations in 11 Pacific Island countries to measure the relative motions of land and sea at each station (South Pacific Sea Level and Climate Monitoring Project 2001). The project is managed by the National Tidal Facility of Flinders University of South Australia. These data will assist in long-term calibration of satellite altimetry and provide a measure of regional vertical control.

The Secretariat of the Pacific Regional Environment Program's (SPREP) Pacific Islands Climate Change Assistance Programme was implemented from $1997-$ 2000 to assist 10 Pacific Island countries that signed and ratified UNFCCC with their reporting, training and capacity-building responsibilities under the convention, including assessing their vulnerability to climate change. Participants from 12 countries (Papua New Guinea was the one participating country with indigenous mangroves) received training on assessing climate change vulnerability and adaptation requirements during a 6 mo training course in 1998. Under 
this program, SPREP (2000) presents general guidelines for Pacific Island governments to incorporate considerations of sea level and climate change into new development planning.

The Regional Wetlands Action Plan for the Pacific Islands (SPREP 1999a) specifies regional actions to monitor mangroves. Action 3.3.1 calls for the development of a regional monitoring program to assess the status of mangroves in the region, evaluate the success of management and conservation actions, and develop more effective management practices. Furthermore, Action 3.3.5 identifies that mangrove swamps, particularly those of low islands, are likely to be sensitive to rise in sea level. It promotes the development of a mangrove monitoring network for identification of changes, which has yet to be established.

SPREP implemented the project Capacity Building for the Development of Adaptation Measures in Pacific Island Countries, in the Cook Islands, Fiji, Samoa, and Vanuatu from 2002-2005. The project's aim was to build capacity of communities in these 4 countries to adapt to climate change, including incorporation of climate change adaptation considerations into national and local planning and budgeting. The project focused on socioeconomic effects and policy development, and did not address coastal ecosystem response to sea level and climate change forces. For instance, SPREP conducted seminars for senior government officials from the 4 participating countries and produced and distributed briefing papers and educational materials to raise awareness of climate change effects and adaptation (Secretariat of the Pacific Regional Environment Programme 2003).

The South Pacific Applied Geoscience Commission (SOPAC) has developed an environmental vulnerability index for application at national scales to provide a quick and inexpensive method to characterize the vulnerability of natural systems at large scales. It is not designed for site-based vulnerability assessments (SOPAC 2003).

\section{CAPACITY-BUILDING PRIORITIES}

We collected information from 10 of the 16 Pacific Island countries and territories with indigenous mangroves to identify capacity-building priorities to address mangrove responses to climate change effects (Fig. 2): American Samoa, Fiji Islands, Kiribati, Marshall Islands, Federated States of Micronesia, Northern Mariana Islands, Palau, Papua New Guinea, Tonga and Vanuatu. These 10 countries and territories contain $84 \%$ of the region's indigenous mangroves (Gilman et al. in press). Table 1 provides a synthesis of the case study results. This section describes: (1) the tech- nical resources needed for the best possible prediction of how a mangrove wetland will respond to projected relative sea level rise and climate change over coming decades, (2) the institutional resources needed to manage and adapt to these mangrove responses to climate change effects, and (3) the technical and institutional areas that are in urgent need of strengthening in the Pacific Islands region.

Hawaii and Tahiti, where mangroves are human introductions (Allen 1998, Ellison 1999), are not included in the assessment, because management authorities in these areas may actively control the alien invasive species (e.g. Smith 2005). While mangrove wetlands have been reported from Niue (Ellison 1999), a Niue government focal point reported that there are no mangrove wetlands in Niue (F. Rex pers. comm.). While one true mangrove species, Excoecaria agallocha, is documented in Niue (Yuncker 1943), this species is only found in dry littoral forest.

\subsection{Analyses of tide gauge data}

A minimum of a $20 \mathrm{yr}$ local tide gauge record is required to obtain an accurate trend in relative sea level (Church et al. 2004a). Many Pacific islands experience tectonic movements that result in substantial differences in local sea level relative to global eustatic trends. In addition to vertical land-level changes from tectonics, change in relative mean sea level over time as measured by a tide gauge can result from subsidence due to extraction of subsurface groundwater or oil, oceanographic processes such as El Niño phases and changes in offshore currents, long-term changes in regional temperature, sediment consolidation, as well as from global sea level change (Komar 1998, Church et al. 2001). The closer the tide gauge is to the mangrove site, the more accurately it will reflect the actual sea level changes that are affecting the mangroves. For sites with a local tide gauge record of $<20$ yr or that are located far from the nearest tide gauge, sea level trends can be accurately calculated using the near global coverage of TOPEX/Poseidon satellite altimetry data combined with historical global tide gauge records (Church et al. 2004a). Pacific Island countries and territories also need the technical capacity to analyze available tide gauge data to determine projected trends in mean sea level and extreme high water events, and incorporate this information into land-use planning.

Most (7 of 10) countries and territories have sufficiently long tide gauge records $(\geq 20 \mathrm{yr})$ to determine accurate trends in mean sea level and extreme high water events (Fig. 3). However, tide gauges of 4 of the 7 countries and territories with the long ( $\geq 20 \mathrm{yr}$ ) tide 


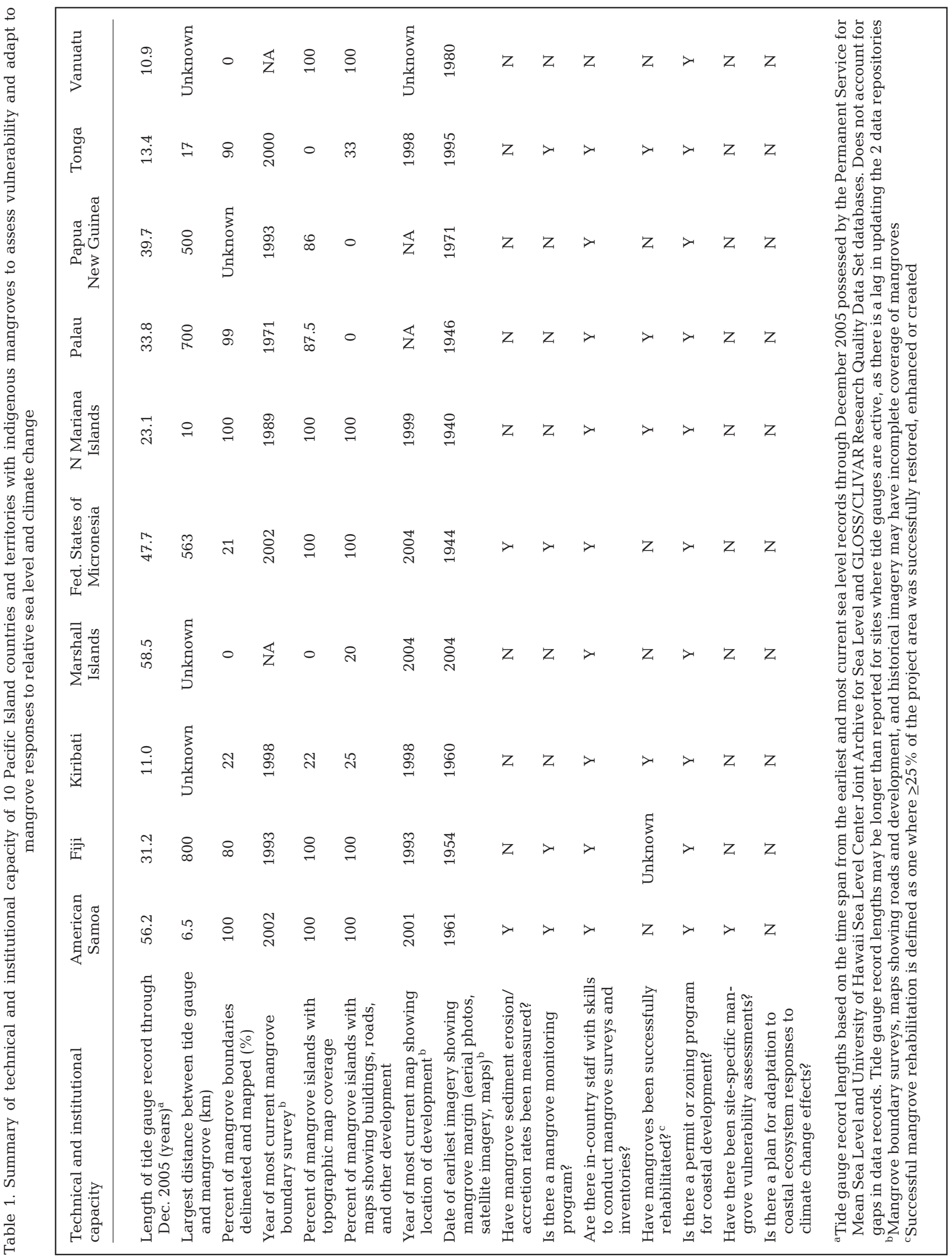




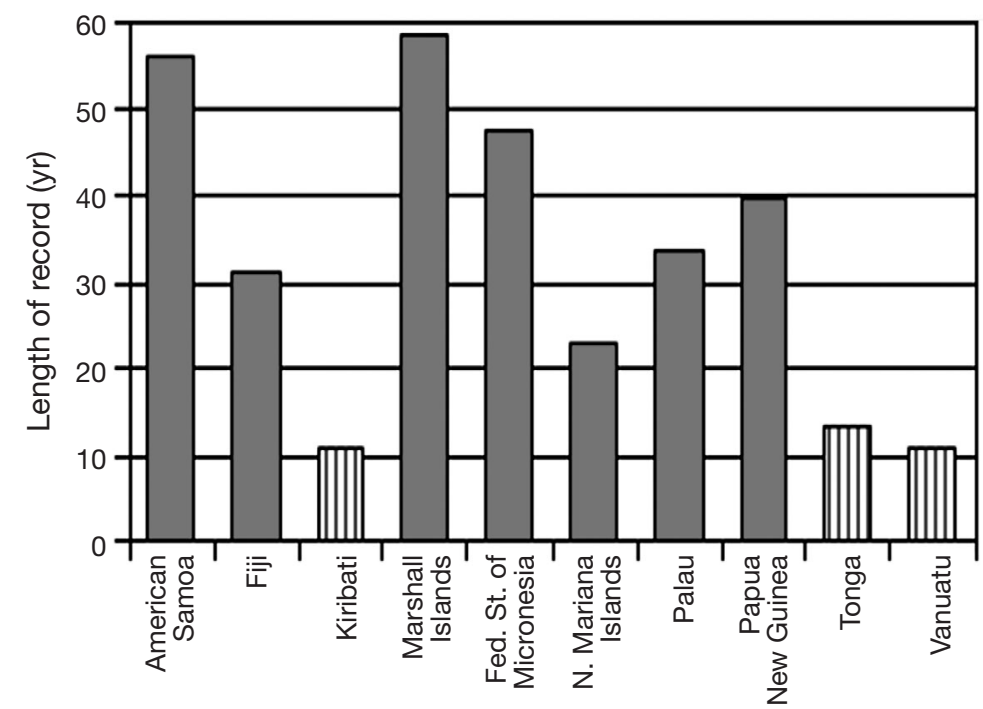

Fig. 3. Length of tide gauge records for 10 Pacific Island countries and territories with indigenous mangroves. Bars with vertical lines have a tide gauge record $<20 \mathrm{yr}$

gauge records are located several hundred kilometers from at least one mangrove site in that country. Three countries with tide gauge records $<20$ yr require assistance to determine reconstructed sea level trends from satellite altimetry data combined with historical global tide gauge records (Church et al. 2004a). Agencies managing coastal land use and coastal ecosystems of Pacific Island countries and territories require assistance to determine trends in relative mean sea level and trends in the frequency and elevations of extreme high water events (Church et al. 2001, Woodworth \& Blackman 2002, 2004, Gilman et al. 2005, in press), and assistance to interpret and incorporate this information into land-use planning.

\subsection{Information on change in sea level relative to mangrove surfaces}

Information on trends in the change in elevation of the mangrove surface is needed to determine how sea level has been changing in recent decades relative to the mangrove surface. The most precise method to obtain information on sea level change is to install an array of tide gauges throughout a site, but this is expensive, laborious, and a minimum of a 20 yr local tide gauge record is required to obtain an accurate trend in relative sea level (Church et al. 2004a). Measurement of ${ }^{137} \mathrm{Cs}$ and excess ${ }^{210} \mathrm{~Pb}$ activity in shallow sediment cores, observing sedimentation stakes, and using soil horizon markers can provide an accurate estimate of rates of change in mangrove surface elevation over recent decades (e.g.
DeLaune et al. 1978, Lee \& Partridge 1983, Lynch et al. 1989, Krauss et al. 2003, Gilman et al. in press), which can then be compared to the relative sea level change rate as measured by the closest tide gauge. The measurement of radioisotope activity in mangrove sediment cores is expensive, especially if multiple cores are taken in an attempt to characterize an entire mangrove site; this method does not account for subsurface processes that affect the elevation of the mangrove surface that occur below the depth of the cores, and there are several potential sources of error, including bioturbation as well as abiotic processes. Alternatively, precision surveying from a benchmark to points throughout a mangrove site could provide information on trends in elevation of the mangrove surface (Cahoon et al. 2002), which could then be compared to the relative sea level change rate from a nearby tide gauge.

American Samoa and the Federated States of Micronesia have some information on mangrove sedimentation rates, obtained from monitoring the change in distance of the mangrove surface from the top of sedimentation stakes and from determining ${ }^{137} \mathrm{Cs}$ and excess ${ }^{210} \mathrm{~Pb}$ activity depth profiles from shallow sediment cores (Krauss et al. 2003, Gilman et al. in press). Otherwise, regionally there is a lack of information on how sea level is changing relative to mangrove surfaces. The mangrove surface can change in elevation from sediment accretion or erosion and from subsurface processes, such as organic matter decomposition, sediment compaction, fluctuations in sediment water storage and water table levels, and root production (Lynch et al. 1989, Krauss et al. 2003, Rogers et al. 2005, Gilman et al. in press). Information on trends in change in the elevation of the mangrove surface over recent decades is needed.

\subsection{Analysis of historical imagery to observe changes in mangrove margin positions}

Analysis of a time series of recent historical aerial photographs and satellite imagery, which show the positions of mangrove seaward margins, can be used to observe trends in movement of the mangrove margins (erosion or seaward progression). This information can then be used to determine if the movement has been correlated with the observed trend in relative mean sea level, and to predict the future position of the seaward margin. Extrapolation from observations of historical shoreline movement is more accurate when 


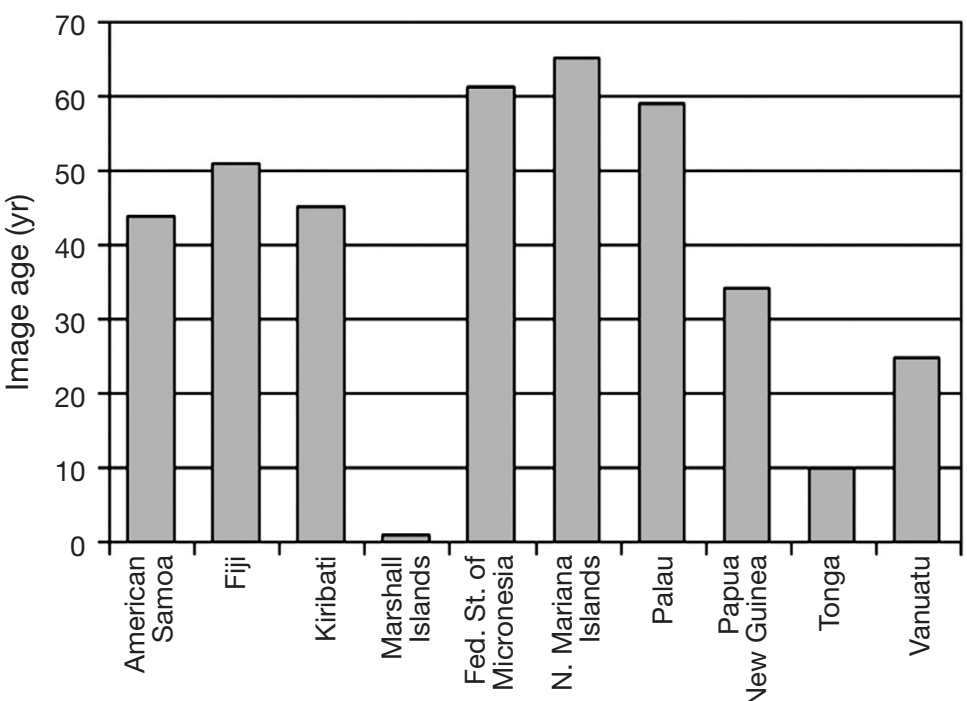

Fig. 4. Age of oldest known historical image showing the location of mangrove margins for 10 Pacific Island countries and territories with indigenous mangroves

the available imagery covers long time periods. The extrapolation assumes that no new large forces, such as human alterations to the coastline's sediment budget, will substantially change the trend from the recent observations.

Historical imagery $\geq 25$ yr old is available for 8 countries and territories (Fig. 4). Only American Samoa has analyzed available historical imagery to observe historical trends in changes in position of mangrove margins (Gilman et al. in press). An effort to identify additional historical aerial photographs, provide IKONOS and QuickBird space imaging to in-country GIS practitioners, and provide assistance to co-register available historical imagery to the geo-referenced satellite imagery is needed. Some countries and territories may need assistance to establish or augment capacity of a GIS program.

\subsection{Mangrove boundary delineation}

Periodic delineation of the mangrove landward margin using GPS or traditional survey techniques is needed to observe any movement of the boundary, providing fundamental information needed to determine trends in mangrove area. Interpretation of remotely sensed imagery (aerial photos and space imaging) generally can be used to delineate the mangrove seaward margin (e.g. Gilman et al. in press), otherwise, delineation with GPS and survey equipment is needed. The world atlas of mangroves (Spalding et al. 1997; a sec- ond edition is due in 2007) includes information on the status and trends in mangrove area.

Five of 9 countries and territories have delineated $80 \%$ or more of their mangrove boundaries (Fig. 5). Two countries have no mangrove boundary delineations. While Papua New Guinea has delineated mangrove boundaries, the percent that has been delineated is not known, and is not included in Fig. 5. Four of the 10 countries and territories have delineated mangrove boundaries within the last 10 yr. This highlights the need by some countries and territories to delineate mangrove boundaries at regular intervals.

\subsection{Map products}

Topographic information is needed to determine the mean slope of the land immediately adjacent to the landward mangrove margins to estimate rates of landward mangrove migration. This requires a recent delineation of the landward mangrove margin. Alternative scenarios for projected change in sea level relative to the mangrove surface can then be used to estimate the distance that the landward mangrove margin will move. If sea level is rising relative to the mangrove surface, then information on the current location of any obstacles to the landward migration of mangroves, such as seawalls, buildings, and roads, and the distance that these structures are from the current landward mangrove margin, is needed to determine how these structures may obstruct future landward mangrove migration.

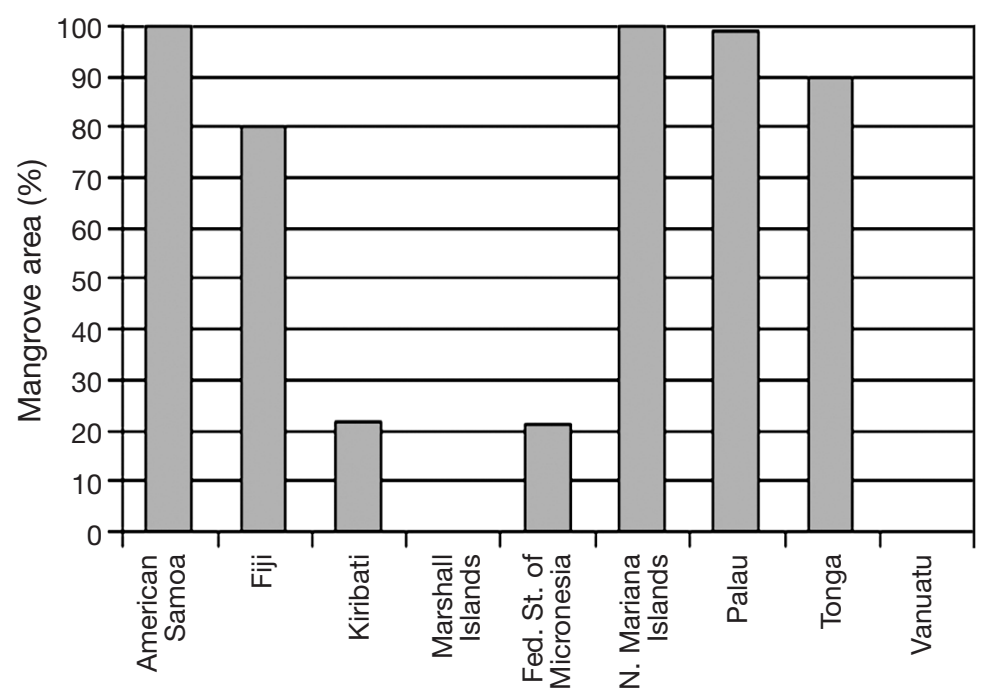

Fig. 5. Percentage of total mangrove area with boundaries delineated for 9 Pacific Island countries and territories with indigenous mangroves 


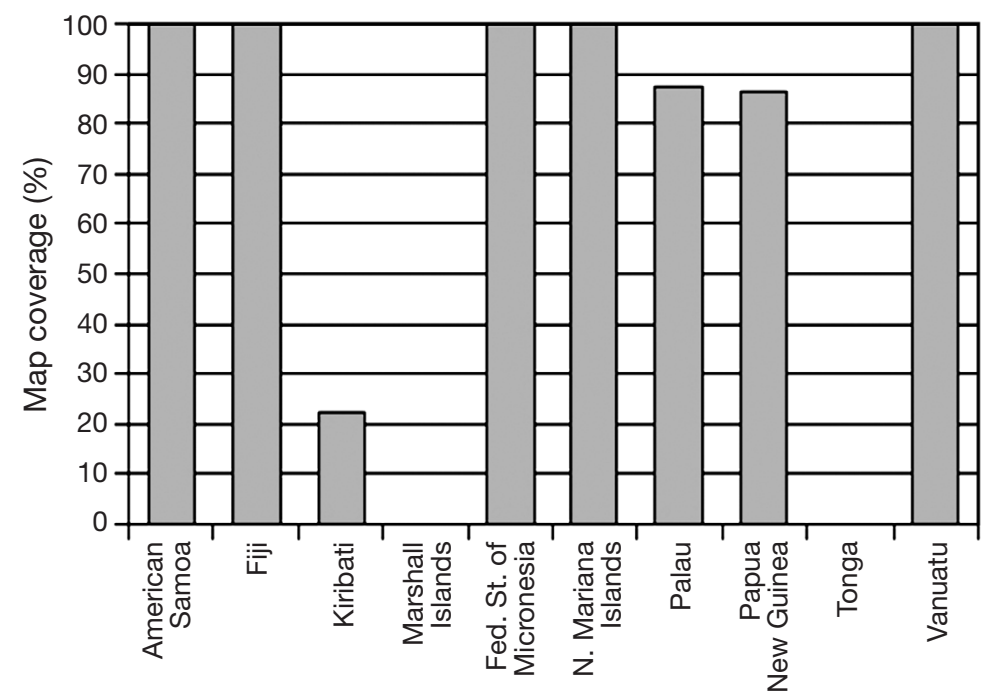

Fig. 6. Percentage of islands containing mangroves with topographic map coverage, for 10 Pacific island countries and territories with indigenous mangroves

Some countries identified a need for topographic maps and maps showing the location of roads and development in the vicinity of mangroves. Support for in-country GIS programs may be needed to produce them. Seven of the countries and territories have $>85 \%$ topographic map coverage of their mangrove islands (Fig. 6). Two lack any topographic map coverage of their mangrove islands. Five countries and territories have maps showing locations of development and roads in the vicinity of all mangroves (Fig. 7). Two countries lack maps showing development and roads next to any of their mangroves.

\subsection{Mangrove monitoring, assessment and regional network}

Given uncertainties about future climate change and the responses of mangroves and other coastal ecosystems, we need to manage adaptively and proactively. In-country staff with training, experience, and motivation are required to conduct monitoring and assessment of relevant mangrove parameters, in part, to facilitate adaptive management. Sea level and climate changes are expected to alter mangrove position, area, structure, species composition, and health. Linking national mangrove monitoring efforts through a regional network using standardized techniques would enable the separation of site-based influences from global changes to provide a better understanding of mangrove responses and alternatives for mitigating adverse effects (Ellison 2000, Nurse et al. 2001).

Four countries and territories identify a strong need for training and capacity-building of in-country personnel in mangrove assessment and monitoring: Vanuatu, Kiribati, Northern Mariana Islands, and Palau. Other countries (American Samoa, Tonga, Fiji, Marshall Islands, Papua New Guinea, and the Federated States of Micronesia) have some in-country capacity already, but identify information gaps. Fiji, Federated States of Micronesia and American Samoa conduct some monitoring of mangrove tree girth (diameter at breast height or DBH), which allows quantitative assessment of mangrove ecosystem change in community structure and growth rates. Palau and Tonga have more limited monitoring, such as of birds or human impacts.

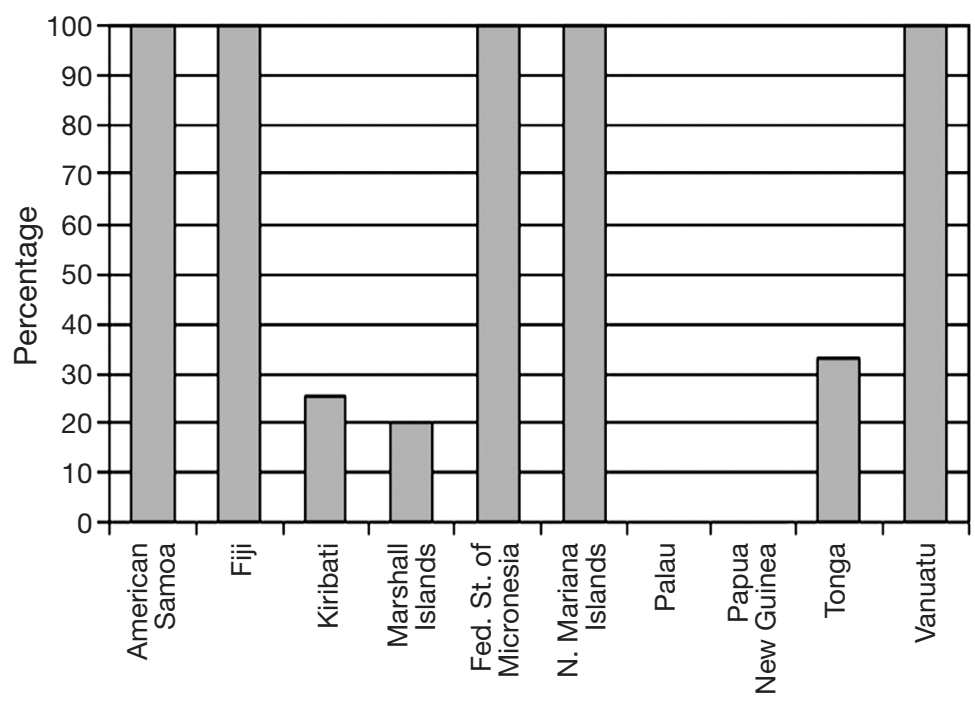

Fig. 7. Percentage of islands containing mangroves with maps showing the location of development and roads, for 10 Pacific Island countries and territories with indigenous mangroves
There has also been no coordination in the limited mangrove monitoring. The countries and territories with a mangrove monitoring program do not employ standardized techniques to enable a meaningful comparison of results from the different programs. Other countries have no monitoring. There is no Pacific Islands regional mangrove monitoring program in place. All countries indicate that they would be interested in participating in a regional network to monitor mangroves and assess mangrove response to sea level rise and climate change, if such a network were established.

Establishing mangrove baselines and monitoring gradual changes through regional networks using standardized techniques will enable the separation of site-based influences from global changes to provide a better 
understanding of mangrove responses to sea level and global climate change, and alternatives for mitigating adverse effects (Ellison 2000, Nurse et al. 2001). The monitoring system, while designed to distinguish climate change effects on mangroves, would also therefore show local effects, providing coastal managers with information to abate these sources of degradation.

Establishing a regional wetland monitoring network for the Pacific Islands region has been proposed in the Action Strategy for Nature Conservation in the Pacific Islands Region (SPREP 1999a), and the Regional Wetlands Action Plan for the Pacific Islands (SPREP 1999b). This has not been implemented to date.

\subsection{Strengthening management frameworks}

Governments need the institutional capacity to manage a land-use permit or zoning program to ensure coastal earthmoving and development activities are sustainable, including accounting for effects on mangroves, and to plan for any landward mangrove migration. While existence of a coastal permit and zoning program does not necessarily mean that current legal and management frameworks and political will are adequately preventing mangrove degradation, it indicates that the institutional capacity needed to sustainably manage activities in mangroves and other sensitive coastal ecosystems exists. Given an existing coastal development permit or zoning program, if the political will exists, it could be possible to establish zoning setbacks for new coastal development adjacent to mangroves in certain sections of coastline, adopt rules on where hard versus soft engineering erosion control structures can and cannot be constructed, and determine which sections of coastline would undergo managed retreat versus fortification.

All 10 participating countries and territories report having some form of coastal permit or zoning program that regulates coastal activities such as earthmoving and development activities. The existence of a framework to manage coastal activities is part of the requisite institutional capacity to sustainably manage activities in mangroves and other sensitive coastal ecosystems. However, this does not necessarily mean that current legal and management frameworks and political will are adequately preventing mangrove degradation. There is a need to assess the efficacy of national management frameworks at preventing mangrove degradation to determine if this is an area in need of attention. For instance, despite the existence of a permit program for coastal development activities, the wetlands management framework in the US Commonwealth of the Northern Mariana Islands has not prevented site-specific, island-wide, or cumulative losses of wetland functional performance or wetland area (Gilman 1998, 1999). Also, Palau's state Public Land Authorities have been leasing and allowing the development of property containing mangroves (Republic of Palau Office of Environmental Response and Coordination 2002).

Only American Samoa has assessed the site-specific vulnerability of mangroves to sea level and climate change (Gilman et al. in press). Information from the case studies and a review of National Communication Reports to the United Nations Framework Convention on Climate Change reveal that none of the 10 countries and territories have developed a plan for adaptation to mangrove or other coastal ecosystem responses to climate change effects. Technical assistance is needed to support conducting site-specific vulnerability assessments and to incorporate this information into land-use and master planning.

\subsection{Mangrove rehabilitation}

Capacity to rehabilitate (restore, enhance and create) mangroves will complement adaptation to mangrove response to sea level and climate change. Restoring areas where mangrove habitat previously existed, enhancing degraded mangroves by removing stresses that caused their decline, and creating new mangrove habitat will help to offset anticipated reductions in mangrove area and increase resilience to climate change effects. If successful mangrove rehabilitation has been achieved in the past, this indicates that it may be possible to replicate this success at other sites. However, failure to provide adequate training to coastal managers in the basics of successful mangrove rehabilitation leads to project failures or projects that only partially achieve stated goals (Lewis 2005).

There has been limited activity in the region in rehabilitation of mangroves, with small-scale successful projects only recorded from Kiribati, Northern Mariana Islands, Palau, and Tonga and 2 failed mangrove rehabilitation efforts in American Samoa and Papua New Guinea. The results of 2 additional rehabilitation efforts in Palau and Fiji are not known. This highlights the need for improved staff training, capacity building and information sharing.

\section{SITE PLANNING AND ADAPTATION STRATEGY}

Management authorities, especially of small island countries and territories, are encouraged to assess site-specific mangrove vulnerability to climate change effects now, and not wait for problems to become apparent, when options for adaptation will be rest- 
ricted. Managers can then incorporate the results of these vulnerability assessments into coastal land-use policies to provide adequate lead-time to minimize social disruption and cost, minimize losses of valued coastal habitats, and maximize available options. The policy adopted to manage site-based shoreline response to rising sea level will be made as part of a broader coastal planning analysis. This analysis requires balancing multiple and often conflicting objectives of managers and stakeholders to (1) sustain the provision of ecological, economic, and cultural values; (2) address priority threats to natural ecosystem functioning; (3) maintain ecological processes and biodiversity; (4) achieve sustainable development; and (5) fulfill institutional, policy, and legal needs (Gilman 2002).

Site planning for some sections of shoreline containing mangroves that are not highly developed and that are experiencing a rise in relative sea level may call for abandonment and adaptation to manage long-term retreat (Dixon \& Sherman 1990, Mullane \& Suzuki 1997, Gilman 2002). 'Managed retreat' involves implementing land-use planning mechanisms before the effects of rising sea level become apparent, which can be planned carefully with sufficient lead time to enable economically viable, socially acceptable, and environmentally sound management measures. Coastal development can remain in use until the eroding coastline becomes a safety hazard or begins to prevent landward migration of mangroves, at which time the development can be abandoned or moved inland. Adoption of legal tools, such as rolling easements, can help make such eventual coastal abandonment more acceptable to coastal communities (Titus 1991). Zoning rules for building setbacks and land use for new development can be used to reserve zones behind current mangroves for future mangrove habitat. Managers can determine adequate setbacks by assessing site-specific rates for landward migration of the mangrove landward margin (Gilman et al. in press). Construction codes can be instituted to account for relative sea level rise rate projections to allow for the natural inland migration of mangroves based on a desired lifetime for the coastal development (Mullane \& Suzuki 1997). Any new construction of minor coastal development structures, such as sidewalks and boardwalks, should be required to be expendable with a lifetime based on the assessed sites' erosion rate and selected setback. Otherwise, the structure should be portable. Rules could prohibit landowners of parcels along these coasts from constructing coastal engineering structures to prevent coastal erosion and the natural inland migration of mangroves. This managed coastal retreat will allow mangroves to migrate and retain their natural functional processes, including protecting the coastline from wind and wave energy.
Employing shoreline erosion control measures, such as surge breakers, dune fencing, and detached breakwaters, can help reduce the rate of coastal erosion (Mullane \& Suzuki, 1997). Use of hard engineering technology, including groins, seawalls, revetments, and bulkheads, a traditional response to coastal erosion and flooding in small island states and worldwide, can increase coastal vulnerability (Fletcher et al. 1997, Mullane \& Suzuki 1997, Mimura \& Nunn 1998, Nurse et al. 2001). These coastal engineering structures usually can effectively halt erosion as relative sea level rises, but often lead to the loss of the coastal system located in front of and immediately downstream in the direction of longshore sediment transport from the structure, converting the seaward coastal system into deepwater habitat (Fletcher et al. 1997, Mullane \& Suzuki 1997). For some sites, it may be less expensive to avoid hard solutions to relative sea level rise and instead allow coastal ecosystems to migrate inland. These ecosystems provide natural coastal protection that may be more expensive to replace with artificial structures (Mimura \& Nunn 1998, Ramsar Secretariat 2001). However, results of site planning may justify use of hard engineering technology and shoreline erosion control measures to prevent erosion for some sections of highly developed coastline adjacent to mangroves. As a result, the mangroves' natural landward migration will be prevented and the mangrove fronting the development will eventually be lost, along with its valued function of buffering the developed coastline from wave and wind energy.

Most cost-benefit analyses included in site planning only examine costs and benefits as measured by market prices, ignoring mangrove and other coastal system values not described by established monetary indicators (Dixon \& Sherman 1990, Ramsar Secretariat 2001). Site planning and cost-benefit analyses employed to determine if a section of coastline abutting a mangrove should be fortified or undergo managed retreat should account for the benefits of allowing mangroves to undergo natural landward migration under a rise in relative sea level. These benefits include the continued provision of valued services and products, including consumptive benefits, education and research, aesthetic and cultural benefits, and future values such as a mangroves future potential for tourism (Dixon \& Sherman 1990, Ramsar Secretariat 2001).

Customary management systems, although weakened, still continue to function at some level throughout the Pacific Islands region (Johannes 1982, Gilman 2002). Community-based approaches, which capitalize on traditional knowledge and management systems, and catalyze stakeholder support for requisite conservation measures, are suitable in some regions. Stake- 
holders will be more likely to comply with restrictions on their traditional resource use activities if they understand and support the rules, which can be accomplished through direct community participation in monitoring, planning, and management decision-making. The optimal approach will depend on the local context. At some sites the rural conditions, including relatively small population size, high dependence of local communities on coastal and marine resources, social cohesion, customary tenure and traditional use of coastal and marine areas and resources, existence of strong and intact traditional authority, and low conventional government management capacity, make local community-based management through collaboration between local government and the local community (e.g. clans or individual villages) appropriate (White et al. 1994). In urban areas with a more heterogeneous local community, more complicated and numerous resource uses and users, more numerous external threats to the coastal and marine environment, and less recognition of customary tenure and traditional governance, community-based management would be less effective and there will be a larger need for central government management.

\section{CONCLUSIONS AND NEXT STEPS}

To assess mangrove vulnerability to sea level rise and other climate change effects and to plan for adaptation, Pacific Island countries and territories need to build their technical and institutional capacity to:

(1) Determine trends in relative mean sea level and trends in the frequency and elevations of extreme high water events, and incorporate this information into land-use planning processes.

(2) Measure trends in the change in mangrove surface elevation to determine how sea level is changing relative to the mangrove surface.

(3) Acquire and analyze historical remotely sensed imagery to observe historical trends in changes in position of mangrove margins.

(4) Produce topographic maps and maps of locations of development and roads for land parcels adjacent to and containing mangroves, and establish or augment GIS programs. The World Bank-funded Infrastructure Asset Management Project in progress in Samoa might serve as a suitable model.

(5) Develop standardized mangrove monitoring programs as part of a regional mangrove-monitoring network. Provide training opportunities for in-country personnel to manage the mangrove-monitoring program, coordinate with a regional hub, and conduct monitoring techniques. Monitoring methods would include periodic delineation of mangrove margins.
(6) Assess efficacy of mangrove management frameworks and provide assistance to manage coastal activities to prevent unsustainable effects on mangroves and other coastal habitats, in part, to increase resilience to climate change effects, and plan for any landward mangrove migration in response to relative sea level rise.

(7) Augment regional capacity to rehabilitate mangroves.

Establishing a regional mangrove monitoring network may enable many of the identified capacitybuilding priorities to be fulfilled, and should be one of the highest regional priorities. Participating countries and territories could share technical and financial resources to maximize monitoring and conservation benefits through economy of scale.

Assessing the efficacy of management frameworks to avoid and minimize adverse affects on mangroves and other valuable coastal ecosystems and plan for any landward mangrove migration is also critical. Ensuring that management frameworks are capable of eliminating and minimizing stresses that degrade mangroves is necessary to provide for mangrove resilience to anticipated stresses from sea level and other climate change effects. And managers will need the institutional capacity to plan for site-specific mangrove response to climate change effects, such as instituting setbacks from mangroves for new development for appropriate sections of coastline. However, management frameworks will only be effective if local communities and management authorities recognize the value of mangrove conservation. It is therefore also a priority to continually develop and augment a mangrove conservation ethic.

The value of wetlands conservation is often underestimated, especially in less developed countries with high population growth and substantial development pressure, where short-term economic gains that result from activities that adversely affect wetlands are often preferred over the less-tangible long-term benefits that accrue from sustainably using wetlands. Mangrove wetlands are one of the most threatened natural communities worldwide, and have lost roughly $50 \%$ of their global area since 1900 (Ramsar Secretariat 1999). Mangroves experiencing stress from other anthropogenic activities such as clearing trees and dumping of pollutants will be less resilient to additional climaterelated stresses. Local communities and leaders must recognize the long-term benefits of mangrove conservation to reverse historical trends in loss of mangrove area, maximize mangrove resilience to climate change, and where sea level is projected to rise relative to mangrove surfaces, enable unobstructed natural landward migration wherever possible. Education and outreach programs are an investment to bring about changes in 
behavior and attitudes by better informing communities of the value of mangroves and other ecosystems. This increase in public knowledge of the importance of mangroves can provide the local community with information to make informed decisions about the use of their mangrove resources, and can result in grassroots support and increased political will for measures to conserve and sustainably manage mangroves.

Acknowledgements. This project was made possible through support to E.L.G. from the United Nations Environment Programme Regional Seas Programme and Western Pacific Regional Fishery Management Council. The authors are grateful for information provided by Taakena Redfern and Aberee Bauro of the Republic of Kiribati Ministry of Environment, Land, and Agricultural Development; Frank Dayton of the US Army Corps of Engineers; Laura Williams of the CNMI Division of Fish and Wildlife; Dr. Leroy Heitz of the University of Guam Water and Environmental Research Institute; Kashgar Rengulbai of the Palau Bureau of Agriculture; Alma Ridep-Morris of the Palau Bureau of Marine Resources; Mike Aurelio of PALARIS; Tiare Holm and Anu Gupta of the Palau Conservation Society; Yimnang Golbuu, Charlene Mersai and Steven Victor of the Palau International Coral Reef Center; Ann Kitalong of The Environment, Inc.; and Umiich Sengebau of The Nature Conservancy. Professor Richard Coleman and Dr. Werner Hennecke of the University of Tasmania, Australia, assisted with case study designs and commented on drafts of this report. Serena Fortuna and Mette Loyche Wilkie, Forestry Department, Food and Agriculture Organization of the United Nations, assisted with identifying national focal points. Neil White, Commonwealth Scientific and Industrial Research Organization, provided mean sea level rates through reconstructed analysis and regression analysis of monthly mean sea levels with tidal constituents removed for some of the countries and territories included in this assessment.

\section{LITERATURE CITED}

Allen JA (1998) Mangroves as alien species: the case of Hawaii. Glob Ecol Biogeogr Lett 7:61-71

Alleng G (1998) Historical development of the Port Royal mangrove wetland, Jamaica. J Coast Res 14:951-959

Cahoon DR, Lynch JC, Perez BC, Segura B, Holland R, Stelly C, Stephenson G, Hensel P (2002) A device for high precision measurement of wetland sediment elevation: II. The rod surface elevation table. J Sediment Res 72:734-739

Church J, Gregory J, Huybrechts P, Kuhn M, Lambeck K, Nhuan M, Qin D, Woodworth P (2001) Changes in sea level. In: Houghton J, Ding Y, Griggs D, Noguer M, van der Linden P, Dai X, Maskell K, Johnson C (eds) Climate change 2001: the scientific basis. Cambridge University Press, Cambridge, p 639-693

Church J, White N, Coleman R, Lambeck K, Mitrovica J (2004a) Estimates of the regional distribution of sea level rise over the 1950 to 2000 period. J Clim 17:2609-2625

Church J, Hunter J, McInnes K, White N (2004b) Sea level rise and the frequency of extreme events around the Australian coastline. In: Coast to Coast '04 - Conf Proc, p 16-24

DeLaune R, Patrick W Jr, Buresh R (1978) Sedimentation rates determined by ${ }^{137} \mathrm{Cs}$ dating in a rapidly accreting salt marsh. Nature 275:532-533

Dixon JA, Sherman PB (1990) Economics of protected areas A new look at benefits and costs. Island Press, Washington, DC

Ellison J (1993) Mangrove retreat with rising sea level, Bermuda. Estuar Coast Shelf Sci 37:75-87

Ellison J (1999) Status report on Pacific island mangroves. In: Eldredge LG, Maragos JE, Holthus PL (eds) Marine and coastal biodiversity in the tropical island Pacific region: Vol 2. Population, development and conservation priorities. Pacific Science Association and East West Center, Honolulu, p 3-19

Ellison JC (2000) How South Pacific mangroves may respond to predicted climate change and sea level rise. In: Gillespie A, Burns W (eds) Climate change in the South Pacific: impacts and responses in Australia, New Zealand, and small islands states. Kluwer Academic Publishers, Dordrecht, p 289-301

Ellison J (2001) Possible impacts of predicted sea level rise on South Pacific mangroves. In: Noye B, Grzechnik M (eds) Sea level changes and their effects. World Scientific Publishing, Singapore, p 289-301

Ellison J (2004) Vulnerability of Fiji's mangroves and associated coral reefs to climate change. University of Tasmania, Launceston

Ellison J, Stoddart D (1991) Mangrove ecosystem collapse during predicted sea level rise: holocene analogues and implications. J Coast Res 7:151-165

Federated States of Micronesia (1997) 1997 Climate Change National Communication. FSM National Government, Climate Change Program, Palikir

Fletcher CH, Mullane RA, Richmond B (1997) Beach loss along armored shorelines of Oahu, Hawaiian Islands. J Coast Res 13:209-215

Gilman EL (1998) Nationwide permit program: unknown adverse impacts on the Commonwealth of the Northern Mariana Islands' wetlands. Coast Manag 26:253-277

Gilman EL (1999) Compensatory wetland mitigation in the CNMI: an incipient discipline. In: Streever W (ed) An international perspective on wetland rehabilitation. Kluwer Academic Publishers, New York, p 3-17

Gilman EL (2002) Guidelines for coastal and marine siteplanning and examples of planning and management intervention tools. Ocean Coast Manag 45:377-404

Gilman E (2004) Assessing and managing coastal ecosystem response to sea level and climate change. UNESCO World Heritage Centre Pacific Project Planning Workshop 5-9 Oct. 2004, Kiritimati Island, Kiribati. Blue Ocean Institute, New York

Gilman E, Coleman R, Hunter J (2005) Trends in frequency and elevation of extreme high water events and causes, American Samoa. University of Tasmania and American Samoa Coastal Management Program, Hobart

Gilman E, Ellison J, Coleman R (in press) Assessment of mangrove response to projected relative sea-level rise and recent historical reconstruction of shoreline position. Environ Monit Assess

Government of Samoa (1999) First National Communication Report to the UNFCCC. Department of Lands, Survey and Environment, Apia

Government of Tuvalu (1999) Tuvalu Initial National Communication Under the United Nations Framework Convention on Climate Change. Funafuti

Holgate SJ, Woodworth PL (2004) Evidence for enhanced coastal sea level rise during the 1990s. Geophys Res Lett 31:7305-7326 
Houghton J, Ding Y, Griggs D, Noguer M, van der Linden P, Dai X, Maskell K, Johnson C (eds) (2001) Climate change 2001: the scientific basis. Cambridge University Press, Cambridge

Johannes RE (1982) Traditional conservation methods and protected marine areas in Oceania. Ambio 11:258-261

Kingdom of Tonga (2005) Initial National Communication in Response to its Commitment under the United Nations Framework Convention on Climate Change. Kingdom of Tonga

Kiribati Government (1999) Initial Communication Under the Convention. Ministry of Environment and Social Development, Tarawa

Komar P (1998) Beach processes and sedimentation, 2nd edn. Prentice Hall, Upper Saddle River, NJ

Krauss KW, Allen JA, Cahoon DR (2003) Differential rates of vertical accretion and elevation changes among aerial root types in Micronesian mangrove forests. Estuar Coast Shelf Sci 54:251-259

Lee W, Partridge T (1983) Rates of spread of Spartina anglica and sediment accretion in the New River estuary, Invercargill, New Zealand. NZ J Bot 21:231-236

Lewis RR III (2005) Ecological engineering for successful management and restoration of mangrove forests. Ecol Eng 24(4 SI):403-418

Lewis RR III (1992) Scientific perspectives on on-site/off-site, in-kind/out-of-kind mitigation. In: Kusler JA, Lassonde C (eds) Effective mitigation: mitigation banks and joint projects in the context of wetland management plans. Proc Natl Wetland Symp, Palm Beach Gardens, FL, p 101-106

Lynch J, Meriwether J, McKee B, Vera-Herrera F, Twilley R (1989) Recent accretion in mangrove ecosystems based on ${ }^{137} \mathrm{Cs}$ and ${ }^{210} \mathrm{~Pb}$. Estuaries 12:284-299

McLean R, Tsyban A, Burkett V, Codignotto J, Forbes D, Mimura N, Beamish R, Ittekkot V (2001) Coastal zones and marine ecosystems. In: McCarthy J, Canziani O, Leary N, Dokken D, White K (eds) Climate change 2001: impacts, adaptation, and vulnerability. Cambridge University Press, Cambridge, p 343-378

Mimura N, Nunn P (1998) Trends of beach erosion and shoreline protection in rural Fiji. J Coast Res 14:37-46

Mullane R, Suzuki D (1997) Beach Management Plan for Maui. University of Hawaii Sea Grant Extension Service and County of Maui Planning Department, Maui

Nurse L, Sem G, Hay J, Suarez A, Wong P, Briguglio L, Ragoonaden S (2001) Small island states. In: McCarthy J, Canziani O, Leary N, Dokken D, White K (eds) Climate change 2001: impacts, adaptation, and vulnerability. Cambridge University Press, Cambridge, p 843-875

Papua New Guinea Government (2000) Initial National Communication Under the United Nations Framework Convention on Climate Change. Government of Papua New Guinea

Phillips B (2000) Vanuatu vulnerability assessment: an approach to integrated regional assessment. In: Mimura N, Yokoki H (eds) Proc APN/SURVAS/LOICZ Joint Conf Coastal Impacts of Climate Change and Adaption in the Asia-Pacific Region, Kobe

Ramsar Secretariat (1999) Global review of wetland resources and priorities for wetland inventory. Meeting of the Conference of the Contracting Parties to the Convention on Wetlands, Ramsar COP7 DOC.19.3, Gland

Ramsar Secretariat (2001) Wetland values and functions: climate change mitigation. Gland

Republic of the Marshall Islands Environmental Protection Authority (2000) Initial Communication Under the United
Nations Framework Convention on Climate Change. Majuro

Republic of Nauru (1999) Climate Change Response. First National Communication under the United Nations Framework Convention on Climate Change. Yaren

Republic of Palau Office of Environmental Response and Coordination (2002) First Communication to the United Nations Framework Convention on Climate Change. Koror

Republic of Vanuatu (1999) Vanuatu National Communication to the Conference of the Parties to the United Nations Framework Convention on Climate Change. Port Vila

Rogers K, Saintilan N, Heijnis H (2005) Mangrove encroachment of salt marsh in Western Port Bay, Victoria: the role of sedimentation, subsidence, and sea level rise. Estuaries 28:551-559

Saintilan N, Wilton K (2001) Changes in the distribution of mangroves and saltmarshes in Jervis Bay, Australia. Wetlands Ecol Manag 9:409-420

SCOR Working Group (1991) The response of beaches to sea level changes: a review of predictive models. J Coast Res $7: 895-921$

Secretariat of the Pacific Regional Environment Programme (2003) Capacity building for the development of adaptation measures in Pacific Island countries project. Biannual report covering the period April 1st 2003-September 30th 2003, Apia

Smith CR (2005) Recolonization and succession of wetland communities following mangrove removal. University of Hawaii Department of Oceanography, Honolulu

Snedaker S (1993) Impact on mangroves. In: Maul GA (ed) Climate change in the Intra-American Seas: implications of future climate change on the ecosystems and socioeconomic structure of the marine and coastal regimes of the Caribbean Sea, Gulf of Mexico, Bahamas and N.E. Coast of South America. Edward Arnold, London, p 282-305

Solomon Islands Government (2004) Initial National Communications Under the United Nations Framework Convention on Climate Change. Solomon Islands Government

Solomon S, Kruger J, Forbes D (1997) An approach to the analysis of storm-surge and sea level vulnerability using GIS: Suva, Fiji, South Pacific. In: Proc 1997 Can Coast Conf. Canadian Coastal Science and Engineering Association, Ottawa

SOPAC (South Pacific Applied Geoscience Commission) (2003) Future directions for the environmental vulnerability index (EVI) project. SOPAC Secretariat, Suva

SPREP (1999a) Regional wetlands action plan for the Pacific Islands. South Pacific Regional Environment Programme, Apia

SPREP (1999b) Action strategy for nature conservation in the Pacific Islands region 1999-2002. South Pacific Regional Environment Programme, Apia

SPREP (2000) Adapting to climate change: incorporating climate change adaptation into development activities in Pacific Island countries: a set of guidelines for policymakers and development planners. South Pacific Regional Environment Programme, Apia

South Pacific Sea Level and Climate Monitoring Project (2001) Precision monitoring with the continuous global positioning system (CGPS). Australian Marine Science \& Technology, Curtin

Spalding MD, Blasco F, Field CD (1997) World mangrove atlas. International Society for Mangrove Ecosystems, Okinawa

Titus JG (1991) Greenhouse effect and coastal wetland policy: 
how Americans could abandon an area the size of Massachusetts at minimum cost. Environ Manag 15:39-58

White A, Hale L, Renard Y, Cortesi L (eds) (1994) Collaborative and community-based management of coral reefs: lessons from experience. Kumarian Press, West Hartford, CT

Woodroffe CD (1995) Response of tide-dominated mangrove shorelines in northern Australia to anticipated sea level rise. Earth Surface Processes Landforms 20:65-85

Editorial responsibility: Joan Kleypas,

Boulder, Colorado, USA
Woodworth PL, Blackman DL (2002) Changes in extreme high water at Liverpool since 1768. Int J Climatol 22: $697-714$

Woodworth PL, Blackman DL (2004) Evidence for systematic changes in extreme high waters since the mid-1970s. J Clim 17:1190-1197

Yuncker TG (1943) The flora of Niue Island. Bernice P. Bishop Museum Bulletin 178:1-126

Submitted: March 21, 2006; Accepted: June 19, 2006

Proofs received from author(s): September 19, 2006 